\title{
ANALYSIS OF THE ADVENTITIOUS FAUNA OF TERRESTRIAL MOLLUSCS IN THE CENTRE OF THE RUSSIAN PLAIN
}

\author{
EVGENIY V. SCHIKOV
}

\begin{abstract}
Tver State University, St. Pos. Kalinina, 37-21, Lyubertsy, Moscow region, Russia, 140002
\end{abstract}
(e-mail: e_v_schik@mail.ru)

\begin{abstract}
The terrestrial mollusc fauna of the central part of the Russian Plain has been analysed with respect to its species composition and the proportion of adventitious species. The classification of adventitious species follows that accepted in Russia. Considerable changes in the fauna took place in the period 2016-2020. Helix lucorum Linnaeus and Cornu aspersum (O. F. Müller) were added to the terrestrial malacofauna of the area. Within the last four years, Arion vulgaris Moquin-Tandon colonised anthropogenic habitats and its spread continues. Krynickillus melanocephalus Kaleniczenko, Arianta arbustorum (Linnaeus), and Helix pomatia Linnaeus are now firmly established in natural ecosystems. Populations of A. vulgaris, $K$. melanocephalus, and $A$. arbustorum have become so abundant that now they cause significant damage to agricultural crops. In both natural and anthropogenic habitats K. melanocephalus and A. arbustorum displace Succinea putris (Linnaeus), Deroceras laeve (O. F. Müller), D. sturanyi (Simroth), D. invadens Reise, Hutchinson, Schunack et Schlitt, D. agreste (Linnaeus), D. reticulatum (O. F. Müller), Fruticicola fruticum (O. F. Müller) and Euomphalia strigella (Draparnaud). Interactions between invasive species are discussed. The proportion of alien species in several European countries and in Central Asia is compared.
\end{abstract}

KEY WORDS: adventitious fauna; gastropods; terrestrial gastropods; interactions between species

\section{INTRODUCTION}

Consequences of the introduction of invasive species are diverse and largely negative. This is observed in both natural and anthropogenic habitats. They enter into a variety of interactions with autochthonous species, as competitors, predators or vectors of parasites and diseases. This, in many cases, leads to impoverishment or even extinction of native mollusc species and sometimes to changes in the structure of whole biocoenoses. The consequences in anthropogenic ecosystems (horticultural and agricultural cultivations) often include grave economic losses. Some introduced species are vectors of parasites and diseases. At the same time, still very little is known about adventitious species and, as the situation is changing rapidly, the processes of introduction should be monitored.

The first alien species in the centre of the Russian plain were recorded in the early 19 th century. At the end of the 20th century, the number of adventitious species began to increase markedly. Because of the explosive character of introductions within the last four years, it seemed necessary to assess the changes since the last survey (SCHIKOV 2016a) and to update the state of knowledge.

\section{MATERIAL AND METHODS}

The basis for this work was the study of the terrestrial malacofauna of natural and anthropogenic habitats of the Moscow, Novgorod and Tver regions [oblasts] of 1963-2020. The research was carried 
out in two periods. The collections from 19632015 were analysed in the previous paper (SCHIKOV 2016a). Further field work was done in 2016-2020 in order to identify changes in the faunas that took place in recent years. Collecting was done in various districts of the Moscow, Pskov and Tver regions. In total, 452 samples were taken. Of these, in 279 cases, the collection was carried out exactly at the same places which had been surveyed in 1963-2015. In many cases, over the past years, the habitats have been radically changed: meadows are now overgrown with forests, floodplain meadows of the Volga are overgrown with tall grasses, pine forests have become mixed pine-small-leaved forests, etc. The survey repeated after a long interval made it possible to trace the changes in the terrestrial malacofauna of a large number of ecosystems: several types of natural and secondary pine and spruce forests, various kinds of natural and secondary deciduous forests (oak, ash, aspen, birch, alder), willow thickets, floodplain and dry meadows, and anthropogenic habitats (botanic garden, parks, lawns, fallow land, abandoned fields with tall weeds, commercial greenhouses).

The materials obtained during the study period were compared with the review data published in 2016 (SCHIKOV 2016a). The results of the comparison were partially published in 2020 (SCHIKOV 2020a). In the general review of the terrestrial malacofauna of the central part of the Russian Plain, the earliest arrivals: Deroceras reticulatum (O. F. Müller, 1774), D. sturanyi (Simroth, 1894), Arion fasciatus (Nilsson, 1822) and Trochulus hispidus (Linnaeus, 1758), are regarded as "partly autochthonous". This is due to the fact that they are native to the central and southern parts of the Moscow and Tver regions and adventitious in the northern parts (SCHIKOV 1979, 1982, 1984, 2016a, SCHILEYKO 1982).

The estimate of the number of species in the faunas of the studied regions was carried out taking into account new records and modern ideas of their systematics (SYSOEV \& SCHILEYKO 2004, SCHIKOV 2007), except for Vertigo lilljeborgi Westerlund, 1868, which I regard as a separate species. The classification of adventitious species of terrestrial molluscs used here follows that developed for Russia (SCHIKOV 2016a).

\section{TERMINOLOGY}

The basic terminology follows that of GŁOWACIŃSKI et al. (2013) and GRIGORIEVSKAYA et al. (2004). Some of the terms are proposed for the first time.

Native, indigenous or autochthonous species are species which live within their natural distribution range. Alien, non-native, introduced, non-indigenous, foreign, or exotic species are species living outside their natural range, where they can form permanent populations. Alien species include species which are not present in natural habitats and species whose appearance in such habitats has been reliably established during long-term studies. Random, accidental or casual alien species are species which are found outside their native range in an area where they cannot form stable populations. This category does not include species that naturally appear outside their natural habitats, such as birds during migration, flood-swept molluscs, etc. Invasive species are alien species which expand their range relatively fast (over several decades) or increase the range of habitats which they occupy.

Adventitious fauna is a group of species in the regional fauna which is heterogeneous in origin and heterochronous in time of advent, formed as a result of migrations, due to direct or indirect human influence. The term is analogous to the "adventitious flora" (GRIGORYEVSKAYA et al. 2004).

Introduction - deliberate introduction of a new species into the fauna by man. Induction is an uncontrolled, spontaneous spread of species as a result of anthropogenic changes in landscapes or accidental importations. I regard occasional importation of molluscs as souvenirs, or importation by merchants for sale in pet shops, as accidental importation.

\section{CLASSIFICATION OF ADVENTITIOUS SPECIES OF TERRESTRIAL MOLLUSCS}

The division of adventitious species into groups was carried out in accordance with the European standards (WEIDEMA 2000, GENOVESI \& SHINE 2004, GŁOWACIŃSKI et al. 2013). Alien species are classified in geographical, chronological, and ecological terms.

\section{DIVISION OF ADVENTITIOUS SPECIES ACCORDING TO THE ORIGIN}

Three groups: $\mathrm{T}$ - transcontinental, i.e. immigrants from other continents; $\mathrm{R}$ - regional, i.e. species from the same continent. The latter are divided in two subgroups: RE - immigrants from Europe, and RA - immigrants from Asia.

Species originating from the Mediterranean countries of Europe and North Africa, from the Black Sea region, the Carpathians and the Transcaucasia, as well as from the Balkans and Asia Minor, are included in group RE. This is based on the fact that their northward spread started from Europe and the Balkans.

\section{DIVISION OF ADVENTITIOUS SPECIES ACCORDING TO THE TIME OF ARRIVAL}

Three groups: A - archaic-advent species arrived in the study area before the 19 th century, $\mathrm{H}$ - histor- 
ical-advent species entered the area from the beginning of the 19th century until 1990, L - latest-advent species were discovered after 1990.

\section{DIVISION OF ADVENTITIOUS SPECIES ACCORDING TO THE DEGREE OF NATURALISATION}

The terminology is analogous to that adopted by botanists (GRIGORYEVSKAYA et al. 2004). Four groups:
DZ - domestizoids are species that live in buildings: houses, basements, vegetable stores, hothouses and greenhouses; CZ - colonozoids, their populations may live in secondary habitats for a long time, but do not spread further; EZ - epecozoids have invaded anthropogenic habitats and continue to spread; AZ agriozoids are adventitious species which are firmly established in natural ecosystems.

\section{RESULTS}

Ninety eight species of terrestrial molluscs were recorded from the territory of the Moscow, Novgorod and Tver regions. They represent 23 families and 49

genera. The autochthonous terrestrial malacofauna of these regions includes 72 species of 21 families and 39 genera (SCHIKOV 1971, 2016b). Ten of them

Table 1. Adventitious species of terrestrial molluscs in the fauna of the central part of the Russian Plain. Source: SCHIKOV

(2016a) supplemented with data from 2016-2020. For explanations of categories see text

\begin{tabular}{|c|c|c|c|c|c|c|c|c|c|c|c|}
\hline \multirow{3}{*}{ No. } & \multirow{3}{*}{ Species } & \multicolumn{3}{|c|}{ Origin } & \multicolumn{3}{|c|}{ Time } & \multicolumn{4}{|c|}{ Naturalisation } \\
\hline & & \multirow{2}{*}{$\mathrm{T}$} & \multicolumn{2}{|c|}{$\mathrm{R}$} & \multirow{2}{*}{ A } & \multirow{2}{*}{$\mathrm{H}$} & \multirow{2}{*}{$\mathrm{L}$} & \multirow{2}{*}{$\mathrm{DZ}$} & \multirow{2}{*}{$\mathrm{CZ}$} & \multirow{2}{*}{ EZ } & \multirow{2}{*}{$\mathrm{AZ}$} \\
\hline & & & $\mathrm{RE}$ & $\mathrm{RA}$ & & & & & & & \\
\hline 1 & Lucilla singleyana (Pilsbry, 1889) & $\times$ & & & & & $\times$ & $x$ & & & \\
\hline 2 & Zonitoides arboreus (Say, 1816) & $\times$ & & & & $x$ & & & $\times$ & & \\
\hline 3 & Oxychilus alliarius (Miller, 1822) & & $\times$ & & & & $\times$ & & $\times$ & & \\
\hline 4 & Oxyxhilus draparnaudi (Beck, 1937) & & $\times$ & & & $\times$ & & & $\times$ & & \\
\hline 5 & Oxychilus translucidus (Mortillet, 1854) & & & $x$ & & $x$ & & & $x$ & & \\
\hline 6 & Boettgerilla pallens (Simroth, 1912) & & & $\times$ & & $x$ & & & $x$ & & \\
\hline 7 & Limax maximus Linnaeus, 1758 & & $\times$ & & & $x$ & & & $x$ & & \\
\hline 8 & Limacus flavus Linnaeus, 1758 & & $x$ & & & $x$ & & $x$ & & & \\
\hline 9 & Lehmannia valentiana (Férussac, 1823) & & $\times$ & & & $\times$ & & $\times$ & & & \\
\hline 10 & Bielzia coerulans (M. Bielz, 1851) & & $\times$ & & & & $\times$ & $\times$ & & & \\
\hline 11 & Deroceras reticulatum (O. F. Müller, 1774) & & {$[\times]$} & & $\times$ & & & & & & \\
\hline 12 & Deroceras sturanyi (Simroth, 1894) & & {$[\times]$} & & $\times$ & & & & & & \\
\hline 13 & Deroceras invadens Reise, Hutchinson, Schunack et Schlitt, 2011 & & $\times$ & & & & $\times$ & $\times$ & & & \\
\hline 14 & Deroceras caucasicum (Simroth, 1901) & & & $x$ & & & $\times$ & & $x$ & & \\
\hline 15 & Krynickillus melanocephalus Kaleniczenko, 1851 & & & $x$ & & & $\times$ & & & & $\times$ \\
\hline 16 & Arion fasciatus (Nilsson, 1822) & & {$[\times]$} & & $\times$ & & & & & & \\
\hline 17 & Arion vulgaris Moquin-Tandon, 1855 & & $\times$ & & & & $\times$ & & & $x$ & \\
\hline 18 & Arion rufus (Linnaeus, 1758) & & $\times$ & & & $\times$ & & & $x$ & & \\
\hline 19 & Arion distinctus Mabille, 1868 & & $\times$ & & & & $\times$ & & $x$ & & \\
\hline 20 & Arion silvaticus Lohmander, 1937 & & $\times$ & & & & $\times$ & & $x$ & & \\
\hline 21 & Helicella candicans (Ziegler, 1841) & & $x$ & & & $x$ & & & $x$ & & \\
\hline 22 & Arianta arbustorum (Linnaeus, 1758) & & $\times$ & & & $x$ & & & & & $x$ \\
\hline 23 & Stenomphalia pisiformis (L. Pfeiffer, 1946) & & & $\times$ & & & $\times$ & & $x$ & & \\
\hline 24 & Harmozica ravergiensis (Férussac, 1835) & & & $x$ & & & $\times$ & & $x$ & & \\
\hline 25 & Trochulus hispidus (Linnaeus, 1758) & & {$[\times]$} & & $\times$ & & & & & & \\
\hline 26 & Cepaea hortensis (O. F. Müller, 1774) & & $\times$ & & & $x$ & & & $\times$ & & \\
\hline 27 & Cepaea nemoralis (Linnaeus, 1758), & & $x$ & & & $x$ & & & $\times$ & & \\
\hline 28 & Caucasotachea vindobonensis (Férussac, 1821) & & $\times$ & & & $x$ & & & & $\times$ & \\
\hline 29 & Cornu aspersum (O. F. Müller, 1774) & & $\times$ & & & & $\times$ & $\times$ & & & \\
\hline 30 & Helix lucorum Linnaeus, 1758 & & $\times$ & & & & $\times$ & & $\times$ & & \\
\hline 31 & Helix pomatia Linnaeus, 1758 & & $x$ & & & $\times$ & & & & & $\times$ \\
\hline & Total $27(31)$ & 2 & 19 & 6 & 4 & 14 & 13 & 6 & 16 & 2 & 3 \\
\hline
\end{tabular}


(13\%) are slugs. The number of species which are introduced in the whole study area is 27 (ca. 27\%) and, including those introduced in a part of the study area (semi-alien species further in the text), it is $31(32 \%)$ in 9 families and 19 genera. They include 11 (15 with semi-alien species) (42\%; 48\%) slug species.

The composition of the adventitious mollusc fauna, with species assigned to each category, is shown in Table 1. Most of the adventitious species in the discussed fauna originate from Europe, relatively few (6) come from Asia, and only two are immigrants from another continent.

The four archaic-advent species (D. reticulatum, D. sturanyi, A. fasciatus, T. hispidus) are native to the southern part of the central part of the Russian Plain while in the northern parts they are adventitious (SCHIKOV 1984). This is due to the fact that the northward spread of these species followed the development of farming: cultivated fields, orchards and gardens. It is impossible to determine when exactly such habitats were invaded, but the Slavs who came to the centre of the Russian plain in the 9th century were engaged in field farming; orchards and vegetable gardens existed already in the Middle Ages (PISTSOVYYE KNIGI MOSKOVSKOGO GOSUDARSTVA 1877, SCHIKOV 1979, 1992). In the analysis of the entire malacofauna of the Moscow and Tver regions, $D$. reticulatum, D. sturanyi, A. fasciatus, and T. hispidus are regarded as autochthonous whereas in the Novgorod and Pskov regions they are immigrants of RE group (semi-alien, marked $[x]$ in Table 1 ).

Fourteen species are historical-advent species (1801-1990, i.e. period of 190 years), while almost as many (13) are latest-advent species of a period of ca. 30 years. Most species of the former group (13 out of 14) originate from Europe or Asia, and most (13) represent CZ group - forming populations in secondary habitats but not spreading any further.

$H$. pomatia was probably introduced by monks to monastery gardens in the 18th century. It was used for food during religious fasts. It was first noted by a specialist in 1802 (DVIGUBSKY 1802, SCHIKOV 2016a). Single populations of $H$. pomatia persisted for more than 100 years. At the end of the twentieth century, a rapid spread of the species began in many regions of Russia. This was due to two reasons. At first, after 1990 , children actively imported $H$. pomatia from Central and Western Europe. Later, numerous attempts were made to breed $H$. pomatia. Most of them failed, but in all cases the discarded snails became successfully established in anthropogenic habitats. In cities, they became common in parks and squares and in gardens on private plots. H. pomatia is a garden pest. At present, it is already firmly established in many natural grey alder stands and willow thickets along river and stream valleys, in small-leaved secondary forests and in natural broadleaf forests in ravines. Its spread continues. Consequences of its interaction with the native fauna are not yet known.

A. arbustorum was first discovered in the Moscow region in 1982 (SCHILEYKO 1982). In 2012-2016, the species was recorded in many sites in the Moscow and Tver regions. Small populations appeared in parks, gardens, and in small anthropogenic smallleaved forests. Large and very abundant populations of $A$. arbustorum live on the edges of natural complexes of spruce forests along busy roads. The population density in forests may exceed $300 \mathrm{indiv.} / \mathrm{m}^{2}$. A arbustorum eats all leaf litter, which leads to the disappearance of Succinea putris (Linnaeus, 1758), Fruticicola fruticum (O. F. Müller, 1774) and Euomphalia strigella (Draparnaud, 1802) (SCHIKOV 2012a, 2016a). The food spectrum of $A$. arbustorum is very wide; it even eats ferns. In spruce forests with A. arbustorum, some plant species are completely eaten up. As a result, the phytocoenoses become dominated by species which are not consumed by A. arbustorum: Lamium album L., Asarum europaeum L., Oxalis acetosella L. (SCHIKOV 2012a, 2016a). Today, A. arbustorum is already found in the Vologda, Leningrad, Moscow, Novgorod, Pskov, Tver and Yaroslavl regions. In many places, the species is firmly established in the fauna of natural grey alder stands. In gardens A. arbustorum is a plague. Its density may reach $2-5$ thousand indiv. $/ \mathrm{m}^{2}$. The former pests of agricultural plants: $D$. reticulatum, D. laeve (O. F. Müller, 1774), or A. fasciatus are disappearing. The damage caused by $A$. arbustorum is significant (SCHIKOV 2020b).

Among the recent arrivals, $H$. lucorum was previously occasionally found in parks in Moscow, but there was no convincing evidence that it formed populations in its new sites (SCHIKOV 2016a). Currently, it is frequent in parks in the centre of Moscow (EGOROV 2017). In the Kolomenskoye district of the Moscow region, the species has moved into a smallleaved forest. On farms in the Moscow and Tver regions, nearly 10 tons of $H$. lucorum per year are produced and sold as a food product.

The most recent arrival (L), and with the date of arrival known, is C. aspersum: in November 2020, 500,000 specimens were imported from the Czech Republic to a snail farm near Kolomna, Moscow region (SCHIKOV 2021). The species is now successfully bred and its stock material is sold to other farms in Russia.

A. vulgaris was first discovered in Russia in 2009, in industrial greenhouses in Tver (SCHIKOV 2016a). In those years, L. maximus occurred in masses and was the main pest in greenhouse cultivations of flowers and shrubs for landscaping of the city. To control the pest, the slugs were collected by the hundreds, and within a year - by the thousands. Over the following years, the density of $A$. vulgaris increased rapidly, and the density of L. maximus dropped con- 
siderably. Currently, L. maximus is very rare in greenhouses. Now A. vulgaris has spread in Moscow and the Moscow region, where it causes serious damage in vegetable gardens.

K. melanocephalus has in recent years rapidly spread throughout the centre of the Russian Plain. Previously, it lived in parks, cemeteries, gardens, and mixed natural and anthropogenic forests along river valleys (SCHIKOV 2012b, 2016a). Currently, it is found in industrial greenhouses, parks, gardens, in deciduous forests, shrub thickets, and even in coniferous forests with abundant growth of grasses. The species has invaded and firmly established itself in natural and anthropogenic forests. In greenhouses, parks and small-leaved forests $K$. melanocephalus displaces species of the genus Deroceras: D. laeve, D. sturanyi, D. agreste (Linnaeus, 1758), D. reticulatum and $D$. invadens (formerly reported as $D$. pollonerae (Simroth, 1889) (DAMYANOV \& LIKHAREV 1975, SCHIKOV 2016a)). If earlier K. melanocephalus was only rarely found in gardens and vegetable crops, now it occurs in masses. In the centre of the Russian plain, it does serious damages to agricultural crops.

\section{DISCUSSION}

The changes in the fauna of terrestrial molluscs which have taken place in the recent decades are enormous. Introductions, not only of molluscs, but of many other groups of organisms, are becoming a serious problem worldwide. They should be considered in terms of their consequences for the native faunas (and floras), economic losses, means of pest and parasite control, possible ways of improving the knowledge of alien species, as well as the reasons for the intensification of the introduction processes.

The dispersal of adventitious species continues, not only in the sense of long-distance dispersal to remote, completely new areas, as a result of which more species are (initially at least) added to the local faunas. Once introduced, many alien species continue their dispersal locally, to areas and/or habitats adjacent to the place of introduction. Moreover, the status and role of such species in the ecosystems are often quite different from those observed within the original distribution range and may change through time. Among the species introduced in the centre of the Russian Plain, O. draparnaudi, O. translucidus, B. pallens, $A$. vulgaris, $C$. hortensis and $H$. ravergiensis may, in the years to come, join the group of epecozoids, and some other species are likely to become agriozoids. K. melanocephalus and A. arbustorum are examples of species which do not cause serious disturbance in the biocoenoses within their native range, doing only moderate damage to agricultural crops. However, having invaded the centre of the Russian
Everywhere, it displaces the previously most important native agricultural pest, $D$. reticulatum. However, replacing one pest with the other is not beneficial to farmers, since $\mathrm{K}$. melanocephalus does more damage to cultivated plants. At the same time, as a species originating from the Caucasus, $K$. melanocephalus is much more resistant to high summer temperatures than $D$. reticulatum. In the context of the current climate warming, this provides undeniable advantages for K. melanocephalus.

Most of the domestozoid species (4 out of 6) are recent arrivals. Half of the colonozoids (8) arrived in historic times; among the remaining eight, seven are recent arrivals. Of the two epecozoids one is a recent arrival and one is historic. Among the three agriozoids one is a recent arrival and two are historic. There is no strict distinction between these groups. Domestozoids can become colonozoids and epecozoids may turn into agriozoids (SCHIKOV 2016a). This happened in 2016-2020. A. vulgaris was a domestozoid, and became an agriozoid. K. melanocephalus, A. arbustorum and $H$. pomatia were epecozoids, and became agriozoids.

Plain, they displace native species and become serious horticultural pests. Populations of A. vulgaris, K. melanocephalus, and $A$. arbustorum have become so abundant that they cause significant damage to agricultural crops. At the same time, they displace the former agricultural pests. The biology of new pests is poorly understood which hinders the development of control measures.

Alien species enter into competitive relationships with each other, and with the native species. Some invasive species displace others. This is observed in both hothouses and greenhouses, as well as in natural biocoenoses. At the same time, there are noticeable changes in all the biogeocoenoses. Though the mechanisms of displacement of some species by others have not been sufficiently studied, in some cases they are quite understandable. For example, the predatory $O$. translucidus and $O$. draparnaudi simply eat T. hispidus and Pseudotrichia rubiginosa (A. Schmidt, 1853) (SCHIKOV 2007). When the density of $A$. arbustorum is very high, the snails eat almost all the leaf litter while other litter-feeders starve to death (SCHIKOV 2020b).

In some cases the situation is more complicated. The displacement of $L$. maximus and species of the genus Deroceras by A. vulgaris and K. melanocephalus in greenhouses cannot be explained by a lack of fresh plant food. The reasons are certainly different. At the same time, it should be taken into account that even within the population of one species, the growth rate 
Table 2. Total number of species and number of alien species according to the time of arrival in selected areas in Europe. Data from GŁOWACIŃSKI et al. (2013), with later modifications, CAMERON (2016) and SCHIKOV (2016a, 2016c and this study). The boundary between the $\mathrm{H}$ and $\mathrm{L}$ groups adopted is the same as that adopted in Russia

\begin{tabular}{lccccrrrr}
\hline \multicolumn{1}{c}{ Area } & Total & Alien & Semi-alien & Alien + semi-alien & A & H & L & unknown \\
\hline British Isles & 129 & 41 & 0 & $32 \%$ & 15 & 14 & 7 & 5 \\
Czech Republic & 171 & 13 & 0 & $8 \%$ & 1 & 5 & 7 & 0 \\
Poland & 178 & 19 & 3 & $12 \%$ & 6 & 10 & 3 & 0 \\
Central Russian Plain & 98 & 27 & 4 & $32 \%$ & 4 & 14 & 13 & 0 \\
Central Asia & 214 & 12 & 0 & $6 \%$ & 0 & 10 & 2 & 0 \\
\hline
\end{tabular}

varies among individuals and various age/size classes occur. As soon as different size groups are formed, smaller individuals stop feeding in the presence of large ones and die of starvation (SCHIKOV, unpublished). This phenomenon further complicates the task of identifying the causes and mechanisms of displacement of some species by others.

It is noteworthy that, apart from life histories, inter-specific interactions, environmental factors and purely geographic distance, much depends on the economic and political history of the country. Table 2 shows some data on native and alien species in four selected European faunas.

The studied area holds a high proportion of alien species, as high as that in the fauna of the British Isles with their much more gastropod-friendly climate and a longer period available for introduction. At the same time, the centre of the Russian Plain has a very high proportion of latest-advent (post-1990) species (Table 3). For political reasons, 1990 was the beginning of mass import of decorative plants from Western Europe, and of the possibility of unrestricted travel abroad. This led to massive importations of alien species (SCHIKOV 2016a). In 1991, the process of introduction of alien species became explosive (SCHIKOV 2016a). The main reasons were the intensification of cargo traffic by road and rail, and the mass trips of Russians abroad, from where not only beautiful shells but also live molluscs were brought as souvenirs. Also, after 1991, with the economic changes, rich villas with gardens and greenhouses began to be built everywhere. To decorate these gardens, seedlings and ornamental plants were brought from various countries. Along with the plants and soil, soil-associated slugs and snails and their eggs were accidentally imported (SCHIKOV 2016a). In contrast, in the British Isles overseas trade and travels have existed for centuries, which is reflected in the high proportion of archaic-advent species, despite the islands being to some degree isolated.

Studies on the terrestrial malacofauna of Central Asia began in the 19th century, but the first alien species were recorded only in the middle of the 20th century (LIKHAREV 1965). The probable reason for their relatively recent penetration of the territory of Central Asia was that the people in Central Asiatic countries had for a long time lived in isolation. Among the 214 terrestrial mollusc species recorded from Central Asia (IZZATULLAYEV 2016), only 12 are alien (SCHIKOV 2016c).

Among the introduced terrestrial species in Central Asia, seven (58\%) are slugs and five (42\%) are snails. The proportion of slugs is higher than in the adventitious malacofauna of the Russian Centre plains (42\%; SCHIKOV 2016a). The situation may be explained by the fact that in the countries of Central Asia, fewer people go on holidays abroad, compared to the number of Russians going out of Europe. Consequently, the citizens of Asia are less likely to bring snails as souvenirs. In contrast, slugs are mainly spread with ornamental plants (SCHIKOV 2016a) and this seems to be the main route of introduction of alien species to Central Asia.

All the adventitious species in Central Asia were introduced by humans and originate from adjacent areas: six from the Caucasus and six from Europe. Ten of them are historical advent species and two are latest advent species.

The absence of domestozoids in Central Asia is not accidental. The warm climate of the region facilitates fast colonisation of anthropogenic habitats and the new arrivals soon become colonozoids.

Natural conditions in the countries of Central Asia are radically different from those of Europe. In Asia, vast areas are occupied by deserts and semi-deserts. Most of the native species live in the mountains. Alien species inhabit anthropogenic habitats with artificial irrigation: orchards, parks, vegetable gardens, greenhouses, botanical gardens, edges of irrigation ditches, irrigation fields. Before the begin-

Table 3. Proportion of archaic-, historical- and latest-advent species in the alien faunas of selected areas. For data sources and time boundaries see heading of Table 2

\begin{tabular}{lrccc}
\hline \multicolumn{1}{c}{ Area } & \multicolumn{1}{c}{ A } & H & L & unknown \\
\hline British Isles & $37 \%$ & $34 \%$ & $17 \%$ & $12 \%$ \\
Czech Republic & $8 \%$ & $38 \%$ & $54 \%$ & \\
Poland & $31 \%$ & $53 \%$ & $16 \%$ & \\
Central Russian Plain & $13 \%$ & $45 \%$ & $42 \%$ & \\
Central Asia & $0 \%$ & $83 \%$ & $17 \%$ & \\
\hline
\end{tabular}


ning of the development of agriculture, there were almost no land molluscs in these territories.

The knowledge of adventitious species is still very scanty. With very few exceptions, what we observe at present is the pattern (distribution) and the process (arrival of new species in areas where they were not observed before). Very little is known of the mechanisms of inter-specific interactions, demographic processes in the populations, effect of environmental factors on these processes, or specific traits which favour introductions in some situations and prevent them in other cases; what even worse, life history traits of introduced populations often differ from those observed within the species' native range. This gap in the knowledge has both theoretical (lack of basic knowledge) and practical (pest control, conservation) consequences. At present we know too little to anticipate the outcome of contact of populations of one species with another, not to mention preventing negative consequences of introductions.

The proportion of adventitious species in any local fauna, and their effect on the local ecosystems, no doubt depend on many different factors. One might expect the size of the invaded area and the number of occupied habitats to be correlated with the time of introduction, local environmental conditions, composition of the local fauna and with historic factors, but also - and probably first and foremost - with the life history traits of the invaders. Regretfully, life history data, in most cases fragmentary, exist only for a fraction of alien species. Life history studies should take priority over any attempts to explain the mechanisms of interactions between the native and the introduced species, or among the introduced species. Practical approach to alien species: devising methods of pest control and conservation of endangered taxa, should be based on a thorough knowledge of life history traits and inter-specific interaction mechanisms.

\section{ACKNOWLEDGEMENTS}

It is my duty to thank Professor BEATA POKRYSZKO (Poland) for the valuable additions to the materials of this article and the correction of the English text. I am very grateful to Dr. HEIKE REISE (Germany) for his help in clarifying the names of the species and to Professor ANDRZEJ LESICKI (Poland) for editing the text.

\section{REFERENCES}

CAmeron R. A. D. 2016. Slugs and snails. HarperCollins Publishers, London.

DAMYANOV S. G., LiKHAREV I. M. 1975. Sykhozemni okhluvi (Gastropoda terrestra). Fauna na Bulgarya 4, Bulgarska Akademya Nauk, Sofia.

DVIGUBSKY J. 1802. Primitiae Faunae Mosquaensis seu enumeratio animalium, quae sponte circa Mosquam vivunt, quam speciminis loco pro gradu Medicinae Doctoris legitime consequendo. Moskva.

EGOROV R. 2017. Helix lucorum lucorum Linnaeus, 1758 (Pulmonata, Helicidae) in the city of Moscow. Malacologica Bohemoslovaca 16: 28-32.

GENOVESI P., SHINE C. 2004. European strategy on invasive alien species. Council of Europe. Nature and environment 137.

GŁOWACIŃSKi Z., OKARMA H., PAWŁOWSKI J., SOlARZ W. (eds). 2013. Gatunki obce w faunie Polski. Available at http://www.iop.krakow.pl/gatunkiobce/ (accessed 12 July 2016).

GrigoryeVSKAYA A. YA., StAROdUbTSEVA Ye. A., KHLYZOVA N. Yu., AgAfonov V. A. 2004. Adventivnaya flora Voronezhskoy oblasti: Istoricheskiy, biogeograficheskiy, ekologicheskiy aspekty. Izdatelstvo Voronezhskogo gosudarstvennogo universiteta, Voronezh.

IZZATULLAYEV Z. I. 2016. Bioraznoobraziye mollyuskov Sredney Azii problema sokhraneniya ikh genofon- da. Naukoviy visnik Uzhgorods'kogo universitetu. Naukovyy visnyk Uzhhorods'koho universytetu. Seriya Biolohiya 40: 51-54.
LIKHAREV I. M. 1965. Nekotoryye faktory, opredelayushchiye rasprostraneniye sinantropnykh nazemnykh mollyuskov. Mollyuski. Voprosy teoreticheskoy i prikladnoy malakologii. Moskva-Leninrad: 48-51.

PistsovyYe KNIGI MOSKOVSKOgO GOSUdARSTVA 1877. Part 1, section 2, Moskva.

SCHIKOV E. V. 1971. Nazemnye mollyuski Kalininskoy oblasti kak potentsialnye promezhutochnye khozyayeva gelmintov. In: SoRoKIN M. G. (ed.). Gelmintologicheskiy sbornik. Uchonye zapiski Kalininskogo gosudarstvenno pedagogicheskogo intstituta 89. Kalininskiy gosudarstvennyi pedagogichesky institut, Kalinin, pp. 149-154.

SCHIKOV E. V. 1979. Fauna nazemnykh mollyuskov naselennykh punktov Valdayskoy vozvyshennosti i sopredelnykh territoriy. Zoologicheskiy zhurnal 58: 969-976.

SCHIKOV E. V. 1982. Fauna nazemnykh mollyuskov prirodnykh i antropogennykh landshaftov Valdayskoy vozvyshennosti i sopredelnykh territoriy. In: INOZEMTSEV A. A. (ed.). Zhivotnyi mir tsentra lesnoy zony Yevropeyskoy chasti SSSR. Izdatelstvo Kalininskogo gosudarstvennogo universiteta, Kalinin, pp. 138-156.

SCHIKOV E. V. 1984. Effects of land use changes on the central portion of the Russian plain. In: SOLEM A., VAN BRUGGEN A. C. (eds). World-wide snails. E. J. Brill, Leiden, pp. 237-248.

SCHIKOV E. V. 1992. Nazemnye mollyuski selskokhozyaystvennykh landshaftov Valdayskoy vozvyshennosti i sopredelnykh territoriy. In: VIKTOROV L. V. (ed.). Fauna i ekologiya zhivotnykh. Tverskoy gosudarstvennyi universitet, Tver, pp. 16-27. 
SCHIKOV E. V. 2007. Novyye nakhodki nazemnykh mollyuskov (Gastropoda, Pulmonata) na Russkoy ravnine, Vestnik Tverskogo gosudarstvennogo universiteta. Ser. Biologiya i ekologiya 22: 118-122.

SCHIKOV E. V. 2012a. Arianta arbustorum (Linnaeus, 1758) (Mollusca, Gastropoda) - agressivnyi vselenets na Russkuyu ravninu. Bioraznoobraziye: problemy izucheniya i sokhraneniya: materialy Mezhdunarodnoy nauchnoy konferentsii, posvyashchonnoy 95-letiyu kafedry botaniki Tverskogo gosudarstvennogo universiteta (Tver, 21-24 noyabrya 2012 g.). Izdatelstvo Tverskogo gosudarstvennogo universiteta, Tver: 380381.

SCHIKOV E. V. 2012b. Krynickillus melanocephalus Kaleniczenko, 1851 (Mollusca, Gastropoda, Agriolimacidae) na Russkoy ravnine. Zhivotnye: ekologiya, biologiya i okhrana: materialy vserossiyskoy nauchnoy konferentsii s mezhdunarodnym uchastiyem. Izdatelstvo Mordovskogo univeristeta, Saransk: 375-378.

SCHIKOV E. V. 2016a. Adventivnye vidy nazemnoy malakofauny tsentra Russkoy ravniny. Ruthenica 26: 153-164.

SCHIKOV E. V. 2016b. Otryad Stebelchatoglaznye. In: ORLOV S. V. (ed.). Krasnaya kniga Tverskoy oblasti. 2nd edition. Tver': Tverskoy Pechatnyi Dvor, Tver, pp. 255-269.

SCHIKOV E. V. 2016c. Nekotoryye adventivnyye vidy nazemnykh mollyuskov (Mollusca, Gastropoda, Pulmonata) v Tsentral'noy Azii. Ruthenica 27 [2017]: 81-86.

SCHIKOV E. V. 2020a. Klassifikatsiya adventivnykh vidov nazemnykh mollyuskov. Nauka, priroda i obshchestvo.
Nauchnoye izdaniye. Materialy Vserossiyskoy konferentsii. Miass: Yuzhno-ural'skiy federal'nyy nauchnyy tsentr mineralogii i geoekologii ural'skogo otdeleniya Rossiyskoy akademii nauk, 2020: 157-159.

SCHIKOV E. V. 2020b. Vodyanaya polevka Arvicola amphibius (Linnaeus, 1758) (Arvicolidae) kak agent biologicheskogo kontrolya drevesnoy ulitki Arianta arbustorum (Linnaeus, 1758) (Mollusca, Gastropoda, Helicidae). Vestnik Tverskogo gosudarstvennogo universiteta. Ser. Biologiya i ekologiya 4: 43-54. https://doi.org/10.26456/vtbio171

SCHIKOV E. V. 2021. Nachalo promyshlennogo razvedeniya v Rossii Cornu aspersum (Müller, 1774) (Mollusca, Gastropoda, Helicidae). Nauchno-prakticheskiy zhurnal "Zametki uchonogo". Yuzhnyi universitet Rostovna-Donu 13: 76-79.

SCHILEYKO A. A. 1982. Nazemnye mollyuski (Mollusca, Gastropoda) Moskovskoy oblasti. In: GILYAROV M. S. (ed.). Pochvennye bespozvonochnye Moskovskoy oblasti. Nauka, Moskva, pp. 144-169.

SYSOEV À. V., SCHILEYKO A. A. 2009. Land snails and slugs of Russia and adjacent countries. Pensoft, Sofia.

WEIDEMA I. R. (ed.). 2000. Introduced species in the Nordic countries. Nord Environment 2000, 13, Nordic Council of Ministers, Copenhagen.

Received: February 3rd, 2021

Revised: February 20th, 2021

Accepted: March 11th, 2021

Published on-line: March 19th, 2021 